\title{
핀란드 대외원조 개관
}

\section{I . 원조목적 및 정책}

\section{1. 원조 목적}

ㅁ1996년 9월에 수립된 'Decision-in-Principle on Finland's Development Cooperation' 에 의 한 핀란드 개발협력의 3 대 목적은 다음과 같음.

(1) 빈곤 완화(Alleviation of Poverty) : 빈곤을 누적 적인 문제로 인식하고 빈곤 문제를 교육 부족, 열 악한 생활환경, 보건, 식수보급, 식량 및 의류 등 다각적인 측면에서 접근함.

(2)환경파괴 예방(Prevention of Environm-ental Threats) : 개도국에서의 환경파괴는 빈곤으로 이 어지는 악순환을 야기하므로 빈곤퇴치를 위해 환 경파괴를 예방해야 함.

(3) 평등, 민주주의 및 인권(Equality, Democracy \& Human Rights) : 평등, 민주주의와 인권이 개발 의 전제 조건으로 안정된 사회의 근간이 됨.

ㅁ1998년 10월 수립된 ‘Finland's Policy on
Relations with Developing Countries' 는 세계 안보 및 경제협력 증진을 추가적으로 핀란드 개발 협력의 목표로 지정함.

2002년 2월에 통과된 'Development Policy: Government Resolution' 에서 유엔의 천년개발 선언(UN Millennium Declaration) 및 빈곤근절 을 핀란드 개발협력의 주요 목적으로 명시함.

\section{2. 원조 정책}

(1) 2004 개발정책에 대한 정부 결정(Development Policy:Government Resolution 2004)

- 핀란드는 ODA 관련 별도의 법률을 제정하지는 않았으나 2004년 2월에 통과된 'Development Policy:Government Resolution 2004' 에서는 $\mathrm{ODA}$ 정책 수립 및 시행에 대한 구체적인 지침 과 업무 총괄기관의 기능 및 관련 정부기관의 역 할 등에 대해 상세히 규정하고 있음.

(2) 핀란드 국제개발협력의 개발정책 목적 실행에 대 
한 결정(Decision-in-Principle:Operationalisation of Development Policy Objectives in Finland's International Development Cooperation) -2001년 2월에 수립된 위 결정문은 개발협력 관 행을 발전시킬 수 있는 조치를 제시하고 수원국 선정 기준 및 협력방법을 명시함.

(3) 개발도상국과의 관계에 대한 핀란드의 정책 (Finland's Policy on Relations with Developing Countries)

-1998년 10월 수립된 위 정책은 개발협력을 핀란 드 외교정책의 중요한 일부로 명시하며 핀란드 의 개발정책 목표를 재확인 함.

-이 정책은 핀란드의 전략적인 목표를 (1)세계안 보 장려 (2)빈곤감소 (3)인권 및 민주주의 증진 (4) 세계적 환경문제 예방 (5)경제 관련 사안에 대한 논의 활성화로 규정함.

(4)핀란드 개발협력에 대한 결정(Decision-inPrinciple on Finland's Development Cooperation) -1996년 9월에 수립된 위 결정문은 핀란드 개발협 력의 주요 목표, 실행방법 및 협력채널을 제시함.

\section{II. 원조체제 및 담당기관}

\section{1. 외교부}

ㅁ 핀란드의 ODA 시행에 있어 유상원조는 물론 무상 원조도 외교부에서 총괄하고 있음.

- 핀란드의 경우, $\mathrm{ODA}$ 의 구체적인 시행을 위한 산하 기관이 없음.
- UN과 EU 등 관련 국제기구 및 $\mathrm{NGO}$ 와 긴밀한 협 력을 통해 구체적인 업무를 직접 수행하고 있음. $-\mathrm{ODA}$ 의 구체적 시행에 있어 $\mathrm{NGO}$ 와 외교부간 협력체계를 구축하기 위해 외교부 개발정책국 산하에 'NGO liaison Unit'을 별도 설치하여 운영중임.

- 외교부 내 개발협력업무 관장 부서

(1)개발정책과-(Dept of Development Policy):주 로 원조관련 업무수행

(2)글로벌 이슈담당과 (Dept of Global Affairs):2003년 신설된 부서로 세계화에 관 련된 문제를 중점적으로 다룸.

(3)지역별 담당과(Geographical Depts):1990년 대에 설립되어 무역, 원조, 정치 및 문화를 총 괄하여 내부적 시너지효과 창출

\section{2. 개발정책 위원회 (Development Policy Committee)}

ㅁㅣㅣㄴ란드는 기본적으로 대외원조를 자국의 외교정 책의 일환으로 시행하고 있기 때문에 핀란드 외교 를 총괄하고 있는 외교부에서 $\mathrm{ODA}$ 관련 업무를 총괄 - 조정하고 있으나 동시에 $\mathrm{ODA}$ 관련 정부 부 처와 민간기관 대표 (NGO, 학계 및 기업 대표 등) 가 참여하는 개발정책 위원회(Development Policy Committee)도 운영하고 있음.

- 개발정책위원회의 주요 기능은 핀란드 $\mathrm{ODA}$ 정 책의 시행에 대한 평가와 정부에 관련 연례보고 서를 제출하는 것이며 제출된 보고서는 차기 연 도의 ODA 시행계획 수립시 반영되고 있음. 


\section{3. 기타기관}

ㅁ 무상원조의 경우, 외교부가 총 원조액의 $70 \%$ 정도 를 집행하고 있으며 나머지 $30 \%$ 정도는 재무부, 교육부, 농업부, 무역산업부, 사회보건부, 노동부 등 관련 부처에서 시행하고 있음.

- 핀란드 정부는 정부 내 많은 부처에서 주관하고 있는 ODA 사업의 효율성과 통일성 제고를 위해 외교부가 핀란드 대외원조 관련 정책개발, 행동 계획 마련, 관련 예산 계획 수립과 집행, $\mathrm{ODA}$ 사업에 대한 모니터링과 사업평가, ODA 관련 인력의 채용과 훈련 및 관련 국제협력 업무를 담 당하도록 하고 있음.

\section{ODA 규모}

2003년도 ODA 규모:US\$558백만(ODA/GNI $0.35 \%)$

- 핀란드 $\mathrm{ODA}$ 의 대부분은 무상원조이며 유상원 조의 비율은 $2 \%$ 이하임.

-2003년 ODA 총액기준으로 볼 때 DAC 22개 회 원국 중 미국(16,254백만불), 일본(8,880백만 불), 프랑스(7,253백만불), 독일(6,784백만불), 영국 (6,282백만불) 등에 이어 16 위이며 $\mathrm{ODA} / \mathrm{GNI}$ 기준으로 볼 때 13 위임.

-1991년 ODA/GNI가 0.81\%로 최고치에 이르렀 던 이후 구소련연방의 붕괴로 인한 경제적 어려 움 때문에 동 비율이 급격히 감소하였음.
〈핀란드 연도별 ODA 및 ODA/GNI 추이〉

(단위: US\$백만)

\begin{tabular}{|c|c|c|c|c|c|c|c|c|c|}
\hline \multicolumn{2}{|c|}{ 1999년 } & \multicolumn{2}{|c|}{ 2000년 } & \multicolumn{2}{|c|}{ 2001년 } & \multicolumn{2}{|c|}{ 2002년 } & \multicolumn{2}{|c|}{ 2003년 } \\
\hline ODA & $\begin{array}{l}\text { ODA } \\
/ G N I\end{array}$ & ODA & $\begin{array}{l}\text { ODA } \\
\text { /GNI }\end{array}$ & ODA & $\begin{array}{l}\text { ODA } \\
/ G N I\end{array}$ & ODA & $\begin{array}{l}\text { ODA } \\
\text { /GNI }\end{array}$ & ODA & $\begin{array}{l}\text { ODA } \\
/ G N I\end{array}$ \\
\hline 416 & 0.33 & 371 & 0.31 & 389 & 0.32 & 462 & 0.35 & 558 & 0.35 \\
\hline
\end{tabular}

※ 자료: OECD, Statistics, Table 4

\section{ODA 지원현황}

\section{ODA 규모: US\$558백만(2003년)}

(1)다자간 ODA 규모: US $\$ 250$ 백만(44.6\%/DAC 평 균 30\%)

〈핀란드가 다자간 원조에 의존하는 이유〉

(1)비용 효율적임

(2) 핀란드 대표부가 없는 지역에 대한 효과적 지원

(3)대상 국가에 대한 전문성이 없을 경우 합리적 지원 가능

-2003년도 기준으로 볼 때 유럽공동체(EC)에 대 한 지원 비율이 $43.2 \%$ 로 가장 높으며 다음으로 유엔기구에 대한 지원이 $31.2 \%$ 임.

(2)양자간 ODA 규모: US $\$ 309$ 백만 $(55.4 \% / \mathrm{DAC}$ 평 균 $72.2 \%)$

\section{〈무상원조 비율〉}

-1990년도 초부터 양자간 ODA 모두 무상원조 형태로 지원 양자간 $\mathrm{ODA}$ 의 큰 비중을 차지하는 긴급원조기 금(Emergency and distress relief)의 큰 비중 (2001년도 US 41백만불 중 US15백만불)이 핀 란드 내의 난민지원을 위하여 쓰여 개발도상국 내의 개발 - 인도적 사업을 위한 재원을 고갈시 킨다는 비난을 받아왔음. 


\begin{tabular}{|c|c|c|}
\hline \multicolumn{2}{|c|}{ 2003년도 다자간 ODA지원 현황 } & (단위: US\$백만 \\
\hline \multicolumn{2}{|c|}{ 다자간기관 } & 2003년도 \\
\hline \multirow[t]{2}{*}{ 세계은행(World Bank) } & IDA & 35 \\
\hline & 기타 & - \\
\hline \multicolumn{2}{|l|}{ 소 계 } & 35 \\
\hline \multirow{4}{*}{$\begin{array}{c}\text { 지역개발은행 } \\
\text { (Regional } \\
\text { Development Bank) }\end{array}$} & 아프리카 개발 은행(AfDB) & - \\
\hline & 아시아 개발 은행(ADB) & 4 \\
\hline & 미국간 개발 은행(IADB) & - \\
\hline & 기타 & 11 \\
\hline \multicolumn{2}{|l|}{ 소 계 } & 15 \\
\hline \multirow{5}{*}{$\begin{array}{c}\text { 유엔기관 } \\
\text { (United Nations Agencies) }\end{array}$} & UNDP & 15 \\
\hline & WFP & 8 \\
\hline & UNICEF & 14 \\
\hline & UNHCR & 8 \\
\hline & 기타 & 33 \\
\hline \multicolumn{2}{|l|}{ 소 계 } & 78 \\
\hline \multirow[t]{2}{*}{ 유럽공동체(EC) } & EDF & 37 \\
\hline & 기타 & 71 \\
\hline \multicolumn{2}{|l|}{ 소 계 } & 108 \\
\hline \multirow[t]{3}{*}{ 기타 다자기구 } & IFAD & 2 \\
\hline & IMF & - \\
\hline & 기타 & 11 \\
\hline 소 계 & & 13 \\
\hline 합 계 & & 250 \\
\hline
\end{tabular}

부채탕감

- 다른 $\mathrm{DAC}$ 회원국들에 비하여 부채탕감(action relating to debt)관련 지원이 적은 편임. 1996년 HIPC Initiative가 처음 도입되었을 때 핀란드는 $\mathrm{HIPC}$ 에 대한 양자간 유상원조 193 백 만 유로를 모두 무상원조로 변환하여 탕감하여 주었음.

※HPC Initiative란 세계은행이 1990년대 중반에 도입 한 개념으로 고채무빈국(highly indebted poor countries을 대상으로 부채를 탕감해주는 운동임.

2003년 양자간 $\mathrm{ODA}$ 의 $41.7 \%(\mathrm{US} 129$ 백만불)는 기술협력(technical cooperation)qnans, $14.6 \%$ (US45백만불)는 긴급지원(Emergency and
Distress Relief), 8\%(US25백만불)는 행정비용, 그 리고 약 2\% (US6백만불)는 NGO지원에 사용되었 음. 다른 DAC 회원국들과는 달리 개발식량지원 (Development Food Aid)은 거의 없음.

ㅁㅍㄴ란드는 바스킷 펀딩(basket funding, 예산지원 (budget support) 및 섹터지원(sector support) 모델 등을 도입하여 실행하고 있음.

- 상기 분야에 1999년 2000년간 매년 US4 9 백만불을 지원

- 예컨대 네팔과 잠비아의 교육사업 및 탄자니아 의 빈곤감소예산을 지원

\section{10대 수원국(2002-2003년 평균 기준)}

$\square 10$ 대 수원국은 모잠비크, 아프가니스탄, 탄자니 아, 세르비아/몬테네그로, 나미비아, 남아공, 베트 남, 니카라과, 에티오피아, 보스니아 순으로, 동 국 가들은 최빈개도국(LDCs) 또는 저소득국(Lowincome countries)으로 분류되는 국가들임. 이들 국가에 대한 지원비율은 전체 $\mathrm{ODA}$ 의 약 64.4\%(양자 및 다자 통합 기준) 점유

-핀란드는 원조규모에 비해 너무 많은 수원국을 지원하고 있다는 지적을 받고 있음.

ㅁ 핀란드 외교부가 발간한 'Implementation Plan for the 2001' 에 의하면 핀란드는 정책적으로 10 개의 수원국을 선정하여 빈곤퇴치를 위하여 장기 적으로 협력하기로 함.

-선정된 수원국으로 이집트, 에티오피아, 케냐, 모잠비크, 나미비아, 니카라과, 페루, 탄자니아, 베트남 및 잠비아이며 이중 5 개의 수원국만 
$\mathrm{LDC}$ 임.

- 핀란드 외교부는 케냐, 니카라과 및 잠비아를 재 평가하고 이집트, 나미비아 및 페루와 같은 중진 국을 수원대상국 지위에서 졸업시킬 예정임.

〈2003년도 상위 10대 수원국 지원 규모 및 점유율〉

\begin{tabular}{c|c|c|c}
\multicolumn{1}{|c}{} & \begin{tabular}{c} 
(단위: US\$백만) \\
\hline 순위
\end{tabular} & $\begin{array}{c}\text { 지원규모 } \\
\text { (2002 2003 평균) }\end{array}$ & $\begin{array}{c}\text { 점유율 } \\
\text { (2002 2003 평균) }\end{array}$ \\
\hline 1 & 모잠비크 & 17 & 3.3 \\
2 & 아프가니스탄 & 14.4 & 2.8 \\
3 & 탄자니아 & 12.9 & 2.5 \\
4 & 세르비아/몬테네그로 & 8.2 & 1.6 \\
5 & 나미비아 & 8.2 & 1.6 \\
6 & 남아공 & 8.2 & 1.6 \\
7 & 베트남 & 7.7 & 1.5 \\
8 & 니카라과 & 6.7 & 1.3 \\
9 & 에티오피아 & 6.7 & 1.3 \\
10 & 보스니아 & 5.7 & 1.1 \\
합계 & & 87.89 & 17.1 \\
ODA 총규모 & & 514 & 87.9 \\
\hline
\end{tabular}

※ 자료: OECD, Statistics, Table 32

〈상위 10 대 수원국 추이-양자간 원조 비율〉

(단위: \%)

\begin{tabular}{|c|c|c|c|c|c|c|}
\hline 순위 & $\begin{array}{c}\text { 국명 } \\
\text { (1992 93) }\end{array}$ & $\%$ & $\begin{array}{c}\text { 국명 } \\
\text { (1997 98) }\end{array}$ & $\%$ & $\begin{array}{c}\text { 국명 } \\
\text { (2002 03) }\end{array}$ & $\%$ \\
\hline 1 & 탄자니아 & 11.2 & 이집트 & 6.2 & 모잠비크 & 3.3 \\
\hline 2 & 잠비아 & 6.3 & 탄자니아 & 4.7 & 아프가니스탄 & 2.8 \\
\hline 3 & 베트남 & 5.6 & 잠비아 & 4.3 & 탄자니아 & 2.5 \\
\hline 4 & 케냐 & 4.0 & 니카라과 & 3.7 & $\begin{array}{c}\text { 세르비아 } \\
\text { 몬테네그로 }\end{array}$ & 1.6 \\
\hline 5 & 스리랑카 & 2.7 & 구유고슬라비아 & 3.3 & 나미비아 & 1.6 \\
\hline 6 & 모잠비크 & 2.7 & 모잠비크 & 3.0 & 베트남 & 1.6 \\
\hline 7 & 이집트 & 2.6 & 케냐 & 2.6 & 남아공 & 1.3 \\
\hline 8 & 수단 & 2.2 & 중국 & 2.1 & 니카라과 & 1.3 \\
\hline 9 & 페루 & 1.6 & 네팔 & 2.1 & 에티오피아 & 1.3 \\
\hline 10 & 나카라과 & 1.4 & 말레이시아 & 2.0 & 보스니아 & 1.1 \\
\hline 합계 & & 40.3 & & 32 & & 17.1 \\
\hline
\end{tabular}

* 자료: OECD, The DAC Journal: Development Cooperation 2004 Report

\section{3. 지역별 지원현황(양자간 ODA 기준)}

2002 2003년 핀란드 개발원조의 지역별 분포는
사하라이남 아프리카에 대한 지원이 229.7 백만불 (44.7\%)로 1위를 차지하고 있으며 아시아지역에 대한 지원이 137.3 백만불(26.7\%)로 그 뒤를 잇고 있음.

-1982 83년 총 ODA의 $68.7 \%$ 를 차지했던 아프 리카 국가들에 대한 지원이 2002 03년에는 47.3\%로 감소한 반면, 유럽 및 아시아에 대한 지원은 $0 \%$ 에서 $8.9 \%, 22 \%$ 에서 $26.7 \%$ 로 각각 증가함. 나머지 지역에 대한 지원은 비슷한 수 준에서 유지되거나 소폭으로 증가함.

〈지역별 지원현황-양자간 원조 비율〉

(단위: \%)

\begin{tabular}{c|c|c|c}
\hline 지 역 & 1982-83 & 1992-93 & 2002-03 \\
\hline 유럽 & 0.0 & 6.5 & 8.9 \\
사하라이북 아프리카 & 5.0 & 12.0 & 2.6 \\
사하라이남 아프리카 & 63.7 & 43.1 & 44.7 \\
북중미 & 3.9 & 9.0 & 7.8 \\
남미 & 3.9 & 2.3 & 3.8 \\
중동 & 1.4 & 2.5 & 5.4 \\
서남아 및 중앙아시아 & 9.6 & 10.9 & 14.4 \\
극동아시아 & 12.4 & 13.6 & 12.3 \\
오세아니아 & 0.1 & 0.1 & 0.1 \\
합 계 & 100 & 100 & 100 \\
\hline
\end{tabular}

※ 자료: OECD, Statistics, Table 32

\section{4. 소득그룹별 지원현황(양자간 ODA 기준)}

2002 03년도 최빈개도국(LDCs)에 48.0\%, 중저 소득국에 $34.0 \%$ 를 지원

- 최빈개도국 $(\mathrm{LDCs})$ 에 대한 지원비율이 지속적으 로 감소하고 있는 추세이며 반면 중저소득국에 대한 지원은 1980 년대 초에 비해 2 배로 증가함. -2001 년 기준으로 핀란드는 96 개 수원국에 대해 ODA 기금 지원. 
〈지역별 지원현황-양자간 원조 비율〉

(단위: \%)

\begin{tabular}{c|c|c|c}
\hline 지 역 & $1982-83$ & $1992-93$ & 2002-03 \\
\hline 최빈개도국(LDCs) & 56.5 & 36.5 & 48.0 \\
기타저소득국(Other LICs) & 25.5 & 22.1 & 16.4 \\
중저소득국(LMICs) & 15.8 & 35.1 & 34.0 \\
고중소득국(UMICs) & 2.1 & 5.9 & 1.7 \\
고소득국(HICs) & - & - & - \\
MADCT ${ }^{1)}$ & 0.1 & 0.4 & - \\
합계 & 100 & 100 & 100 \\
\hline
\end{tabular}

1) More Advanced Developing Countries and Territories(동 국가에 대한 지원은 $\mathrm{OA}(\mathrm{Official}$ Aid)로 분류)

※ 자료: OECD, Statistics, Table 32

\section{5. 분야별 지원현황(2003년도)}

ㅁ원조예산의 큰 비중(46.3\%)을 사회 및 행정 인프 라에 지원함.

-1990년대부터 빈곤감소 ODA 정책의 주요 현안 으로 채택하면서 빈곤문제를 보다 효과적으로

다루기 위해 사회 및 행정 인프라 분야를 중점적 으로 지원

2000 01년 기초 사회 서비스-(기초교육, 기초보

건, 영양, 식수 및 위생)에 대한 지원이 양자간 $\mathrm{ODA}$ 의 $11.6 \%$ 를 차지하여 $\mathrm{DAC}$ 평균인 $14.8 \%$ 보 다 현저히 낮은 편에 속함.

ㅁ사회 행정 인프라 분야 및 긴급원조는 10 년 전 $15.9 \%$ 및 $3.7 \%$ 에 비해 2002 03년도에는 $49.3 \%$ 및 $11.9 \%$ 로 크게 증가한 반면 나머지 분야는 대부 분 감소세를 보임.
〈2003년도 분야별 지원실적〉

(단위: \%)

\begin{tabular}{|c|c|c|}
\hline \multicolumn{2}{|l|}{ 분야 } & 2003년도 \\
\hline $\begin{array}{c}\text { 사회 및 행정 인프라1) } \\
\text { (Social and administrative } \\
\text { infrastructure) }\end{array}$ & $\begin{array}{c}\text { 교육(기초교육) } \\
\text { 보건(기초보건) } \\
\text { 인구 } \\
\text { 식수 및 위생 } \\
\text { 정부 및 시민사회 } \\
\text { 기타 사회인프라/서비스 }\end{array}$ & $\begin{array}{c}10.6(0.8) \\
8.1(2.0) \\
1.3 \\
4.4 \\
16.9 \\
4.9\end{array}$ \\
\hline 소 계 & & 46.3 \\
\hline $\begin{array}{c}\text { 경제인프라2) } \\
\text { (Economic infrastructure) }\end{array}$ & $\begin{array}{c}\text { 교통 및 통신 } \\
\text { 에너지 } \\
\text { 기타 }\end{array}$ & $\begin{array}{l}1.7 \\
3.6 \\
1.6\end{array}$ \\
\hline 소 계 & & 7.0 \\
\hline $\begin{array}{c}\text { 생산 } \\
\text { (Production) }\end{array}$ & $\begin{array}{c}\text { 농업 } \\
\text { 제조업, 광업 및 건축 } \\
\text { 무역 및 관광 }\end{array}$ & $\begin{array}{l}2.2 \\
1.4 \\
0.5\end{array}$ \\
\hline 소 계 & & 4.0 \\
\hline $\begin{array}{r}\text { 다부문(Multise } \\
\text { 프로그램원조(Programm } \\
\text { 부채탕감(Action relat) } \\
\text { 긴급원조(Emerger } \\
\text { 행정경비(Administrati) } \\
\text { 기타(Unspecit }\end{array}$ & $\begin{array}{l}\text { assistance) } \\
\text { to debt) }{ }^{3)} \\
\text { aid) } \\
\text { expenses) } \\
\text { d) }\end{array}$ & $\begin{array}{c}15.5 \\
3.1 \\
- \\
11.5 \\
6.8 \\
5.9\end{array}$ \\
\hline 합 계 & & 100 \\
\hline
\end{tabular}

1) 학생 및 연수생 포함 2)인구 및 생식보건 3)비ODA 부채탕감 포함 ※ 자료: OECD, Statistics, Table 19

2003년도 부채탕감/ODA 비율은 $1.2 \%$ 로 DAC 평 균인 $13 \%$ 에 크게 못 미치고 있으며 모두 HIPC (Highly Indepted Poor Country)의 부채탕감을 위하여 쓰여졌음.

〈분야별 지원실적 추이〉

\begin{tabular}{c|c|c|c|c|c|c|c}
\hline \hline 지원년도 & 사회/행정인프라 & 경제인프라 & 농업 & 산업/기타생산 & 물자/프로그램지원 & 긴급지원 & 기타 \\
\hline 1982-83년 & 15.9 & 21.1 & 16.9 & 35.1 & 0.2 & 3.7 & 7.2 \\
2002-03년 & 49.3 & 5.4 & 4.3 & 2.2 & 2.6 & 11.9 & 24.4 \\
\hline
\end{tabular}

※자료:OECD, Statistics, Table 19 


\section{$\mathrm{V}$. 주요 의제별 정책}

\section{1. 빈곤감소}

ㅁ수원국의 거시경제정책에 개입하는 등 수원국 국 가 빈곤 감소 전략을 적극적으로 지원

-핀란드 정부의 지원이 수원국 중앙정부에 집중 화되는 현상을 막고 빈곤층이 많은 지방에 지원 이 효과적으로 제공되도록 PRSP 내의 전략적 변화를 반영시키고 있음.

-핀란드의 개발정책은 $\mathrm{DAC}$ 의 빈곤감소 지침 (DAC Guideline on Poverty Reduction)과 일 치함.

- 핀란드 정부는 빈곤감소를 다면적인 문제로 인 식하고 있으며 다양한 정책을 통해 이를 접근하 고 있음.

ㅁ 핀란드 정부는 성과 및 결과에 대한 상호 책임성을 지지하고 있지만 $\mathrm{ODA}$ 예측가능성 $(\mathrm{pre}-$ dictability) 측면에서는 부족함.

-ODA 공약 및 지출액을 수원국에 통지하는 시스 템이 존재하지 않음.

ㅁ 빈곤감소를 위한 새로운 지원 유형(modalities)를 적극적으로 지지하고 있으며 ODA가 수원국의 국가 예산에 완전히 반영되어야 된다고 믿는 바, 동 취 지에서 수원국에 대한 예산지원(budget support) 을 늘려나갈 예정임.

- 담당 직원들이 이러한 새로운 지원 형식을 활용 하는데 필요한 능력을 배양할 수 있도록 교육에 투자하는 등 조직적 변화를 실행하고 있음.

\section{2. 반부패}

ㅁ부패방지는 빈곤감소, 환경보존, 평등 - 민주주의 및 인권 등 핀란드 정부의 개발협력 목표를 달성하 기 위한 핵심적 정책임.

개발협력사업에 적용될 수 있는 반부패 지침서인 『Preventing Corruption : a Handbook of Anti-Corruption Technique for Use in International Development Cooperation』를 2001년에 발행

-이 지침서는 원조조화(harmonization)를 장기 적으로 부패를 감소시키기 위한 가장 효율적인 방법이라고 지적함. 특히 투명하고 모든 당사자 에게 동일하게 적용되는 조달 규제를 통해 부패 를 예방할 수 있다고 함.

\section{〈〈반부패 지침서의 주요 내용》〉}

(1)국제기구와의 협력(Collaboration with Int' | Organizations): 국제협약 작성 및 다자간 토론회장에 서 부패관련 논의 장려. 국제금융기구 및 유엔기구의 반부패 프로젝트 지원.

(2)반부패 전략(Anti-Corruption Strategies):(i)수원국 내의 정책수립 및 사법 기관과의 협력을 통한 반부패법의 개 정, (ii) 부패가 심각한 공공부문 식별, (iii) 반부패 절차 수 립 (iv)공공부분과 민간부문 및 종교단체를 포함한 시민 사회의 협력강화를 통해 수원국의 반부패전략 지원

(3)핀란드 개발협력의 부패위험 감소 장치(Mechanisms to Reduce Risk of Corruption in Finnish Development Assistance):(i) 협약 내의 법적으로 실효 성이 있는 반부패 조항을 포함 (ii) basket funding 또는 
〈2000-01년 반부패 프로젝트〉

\begin{tabular}{c|c|c|c}
\hline \hline 분야 & 사업 & 지원액(US천불) & 년도 \\
\hline 아프리카(비특정) & 아프리카 역량개발 재단의 거시경제 연구 지원 & 1,807 & 2001 \\
탄자니아 & 반부패 작업 지원 & 1,100 & 2000 \\
아프리카(비할당) & Good Governance를 위한 아프리카 개발은행 위탁기금 & 1,056 & 2002 \\
시르비아·몬테네그로 & 국제투명성의 책임성 프로그램 & 1,037 & 2002 \\
LDCs(비특정) & 국제투명성 및 핀란드 반부패 전문가 지원 & 294 & 2000 \\
나미비아 & 재정부의 예산 체계화 및 정부지출 감시 역량개발 & 226 & 2001 \\
LDCs(비특정) & 최고 심사 단체 국제기구의 공공계정 심사(노르웨이 오슬로) & 38 & 2001 \\
\hline
\end{tabular}

예산지원 시 적절한 실행 기관, 행정적 규제 및 책임성 존재, 감사절차 존재 여부 등을 감안하여 사업지원 여 부를 결정 (iii)투명하고 공개적인 절차를 통해 개발협력 프로젝트를 실행할 컨설팅회사를 선정

(4)특정 반부패 프로젝트(Specific Anti-Corruption Projects): 반부패 사업에 대한 재정적 지원

ㅁ정부 내의 반부패 개념 및 도구들의 효과적인 전 파를 위하여 워크숍, 세미나 등을 실시하여 반부패 지침서의 실질적인 실행을 도모함.

\section{3. 정책일관성}

ㅁㅣㅣㄴ란드 정부는 정책 일관성을 매우 중요한 의제로 생각하고 있으며 이를 실현하기 위하여 비전을 세 우고 조직을 일부분 개편하였으나 명확한 정책, 정 치적 의지 및 분석역량을 갖추지는 못한 실정임.

(1)정책적 일관성을 달성하기 위한 비전:"개발도 상국과의 관계에 대한 핀란드의 정책은 대외 · 안보 정책, 통상 정책 및 국제협력정책의 목적 을 일치시키고 조정하는데 있음"

(2) 정책적 일관성을 달성하기 위한 조직

- 핀란드 외교부 내에 개발을 위한 정책 일관성을 위한 부서는 따로 존재하지 않지만 통상 및 대외
정책이 외교부 내에서 다루어짐으로써 정책적 일관성을 달성할 가능성을 높임.

-정부부처간 시너지를 창출하기 위하여 시민사 회 대표들을 포함한 여러 위원회를 운영중임.

-외교부는 환경부, 그리고 사회 및 보건부와는 정책 일관성 추진 합의에 성공하였지만 통상부 와는 이견이 많음.

- 외교부 내의 공적개발원조 업무를 대외통상 업 무와 완전히 통합시켰으며 각 지역별 부서 내에 서 원조, 통상, 정치 및 문화 등에 대한 정책이 일괄적으로 이뤄지므로 정책적 일관성을 달성 하기 용이해짐.

민란드의 주요 정책적 일관성 의제:대부분의 주 요 정책들은 개발협력 목적에 크게 부합하지만 농 업 및 무이자 차관 등의 분야에서는 개선해야 할 점들이 많음.

(1)농업정책

-농업에 대한 핀란드 정부의 지원은 유럽공동체 (EU) 국가들 중 가장 높음.

$\mathrm{GDP}$ 의 $3 \%$ 를 차지하는 농업은 취약한 기후조건 때문에 많은 보조금이 필요하며 2001년 기준으로 170 억 $\mathrm{EURO}$ 상당의 농업보조금을 핀란드 정부 
(58\%) 및 $\mathrm{EC}$ 의 공 동 농 업 정 책 (Common Agricultural Policy)(42\%)를 통해 지원

-1995년 EU 가입시 취약산업분야(Least

Favored Areas)에 대한 새로운 지원제도를 도 입케 하여 농촌에 대한 보조를 두 배로 늘림.

(2)무이자 차관(Concessional Loan)

- 공여국의 수출을 통해 국내 경제를 활성화시키 기 위한 방법으로 흔히 쓰이고 있으나 이러한 차 관이 빈곤감소를 위해 이용되지 않아 비판을 받 고 있음.

- 핀란드의 경우 1987 년부터 이런 제도를 도입하 였으며 핀란드 수출보증기관과 핀란드 외교부 의 협력 하에 운영되고 있음.

-1991년까지 급성장하였으나 무역왜곡 현상 때 문에 OECD국가들은 1991년 헬싱키에서 무이자 차관에 대한 보다 엄격한 규제를 설립함.

현재 핀란드의 무이자 차관은 헬싱키 규제를 따르 고 있으며 차관의 절반은 시장에서 투자를 유치하지 못하는 사회 인프라 및 환경 관련 분야에 이용되고 있음.

ㅁㅡㅡㄱㅎㅣ 농업분야에서 $\mathrm{EU}$ 의 공통농업정책(CAP: Common Agricultural Policy)은 유럽의 농민들 에게 보조금을 제공하는데 이는 개도국의 농업 분 야에서의 생존능력에 영향을 미치게 됨에 따라 핀 란드 개발협력 정책수립 및 우선 순위 결정등에 영 향을 줌.

\section{4. 비조건부(Untied) 원조}

ㅁ 원칙적으로 모든 기술협력(Techical cooperation)에
대한 원조는 비조건부 원조임. 그 결과 비용효율성 을 제고하고 수원국의 주인의식을 증진시킬 수 있 었음.

ㅁ 기술협력 및 행정비용을 제외한 양자간 ODA의 약 86\%가 비조건부(untied)로 지원됨.

〈2003년 양자간 ODA 지원조건-Tying Status〉

(단위 : US백만불/\%)

\begin{tabular}{cc|cc|cc|cc}
\hline \multicolumn{2}{c|}{ 비조건부 } & \multicolumn{2}{|c|}{ 부분조건부 } & \multicolumn{2}{|c|}{ 조건부 } & \multicolumn{2}{c}{ 총 ODA } \\
\hline 금액 & $\%$ & 금액 & $\%$ & 금액 & $\%$ & 금액 & $\%$ \\
192 & 85.8 & - & - & 32 & 14.2 & 224 & 100 \\
\hline
\end{tabular}

※ 기술협력 및 행정 비용 제외

※ 자료: $\mathrm{OECD}$, Statistics, Table 24

\section{VI. 조직운영}

\section{1. 개발협력 조직}

ㅁ외교부 조직 하에 3 개의 동등한 장관직이 있으며 3장관 모두 각료임.

(1)대외통상 및 개발협력 장관(Minister for External Trade and Development Cooperation)

(2)외무장관(Minister for Foreign Affairs)

(3)환경장관〈북유럽 협력〉(Minister for Environment 〈Nordic Cooperation〉)

\section{2. 주요부서}

(1) 개발정책과(Department for Development Policy)

기능:외교부 내에 개발협력 업무만 다루는 유일 한 부서 
$\square$ 업무영역

-정책 및 연구

-운영 및 재정 관련 계획 및 감시 기능, 통계 및 보고 기능

-품질조정 및 지침개발

-평가 및 내부심사

-관련 국제협약, 법안 준비 및 기타 법적 문제 관 련 업무

- 국제 및 국내 NGO 지원

- 도서관 서비스를 포함한 대내·외 정보통신 관리

$-\mathrm{EU}$ 및 $\mathrm{OECD}$ 내의 개발협력 관련 업무

- 국제기구에 재직 중인 핀란드 전문가 모집 및 교육

$-F I N N F U N D$ 및 무이자 차관 정책

(2) 지역과(Geographical Departments)

ㅁ 4개의 지역과:(1)유럽과(Dept for Europe) (2)아

시아 및 미주과-(Dept for Asia and the Americas)

(3) 동유럽 및 중앙아시아과(Dept for Eastern Europe and Central Asia), (4)중동 및 아프리카 과-(Dept for the Middle East and Africa)

ㅁ업무영역

- 핵심 업무로서 정무, 통상, 개발협력 및 문화 관 련 사안들에 대한 협력방안을 국가별로 기획하 고 집행함.

-지역 및 국가별 정책일관성 달성

- 양자간 개발협력 프로그램의 실행

(3) 글로벌 이슈 담당과-(Dept for Global Affairs)

2003년 설립되어 세계화 관련 사안들에 대한 협력, 조정 및 일치 기능을 외교부 내 그리고 외교부와 국 내 이해당사자(stakeholders) 간에 수행하고 있음.
ㅁ주로 UN, 국제금융기구, 환경 및 인권 문제 그리 고 인도주의 관련 현안 관련 업무를 담당하고 있으 며 양자간 사업을 통해 습득된 경험이 국제기구에 반영되고 국제적 이슈들이 외교부 업무에 반영되 도록 함.

ㅁ국회의원들에게 국제적 사안 및 행사(도하, 몬테 레이, 요하네스버그 정상회의 등)에 대한 정보를 제공함.

\section{3. 개발협력국의 인력관리}

1) 직원규모(2002년 기준)

-외교부 전체 직원수:973명(파트타임 인력 포함)

- 개발협력 업무수행 직원수: 160 명(외교부 전체의 $16 \%)$

\section{2) 직원구성}

- 현재는 대부분 일반 직업 외교관(1990년대 초부

터 원조전문가에 대한 모집을 중단)

-지역과 내에 빈곤, 양성평등, 보건 등 분야별 자 문관이 20명 있음.

\section{3) 인력운영상 문제점}

(1) 핀란드 외교부 내 인력의 부족으로 개발협력업무의 실행, 조정 및 협력에 부정적인 영향을 미치고 있음. -US10백만불 규모의 ODA를 집행하기 위하여 약 6 7명의 직원이 필요함.

- 일반 외교직 직원(generalist diplomatic staff) 으로 부족 인력을 충원한 결과, 기존 전문가들의 업무부담 증가

- 인력부족의 주요 원인으로 (i)예산규모에 비해 분산된 개발협력 사업 (ii)전문가가 아닌 일반 외 
핀란드 외무부 조직도

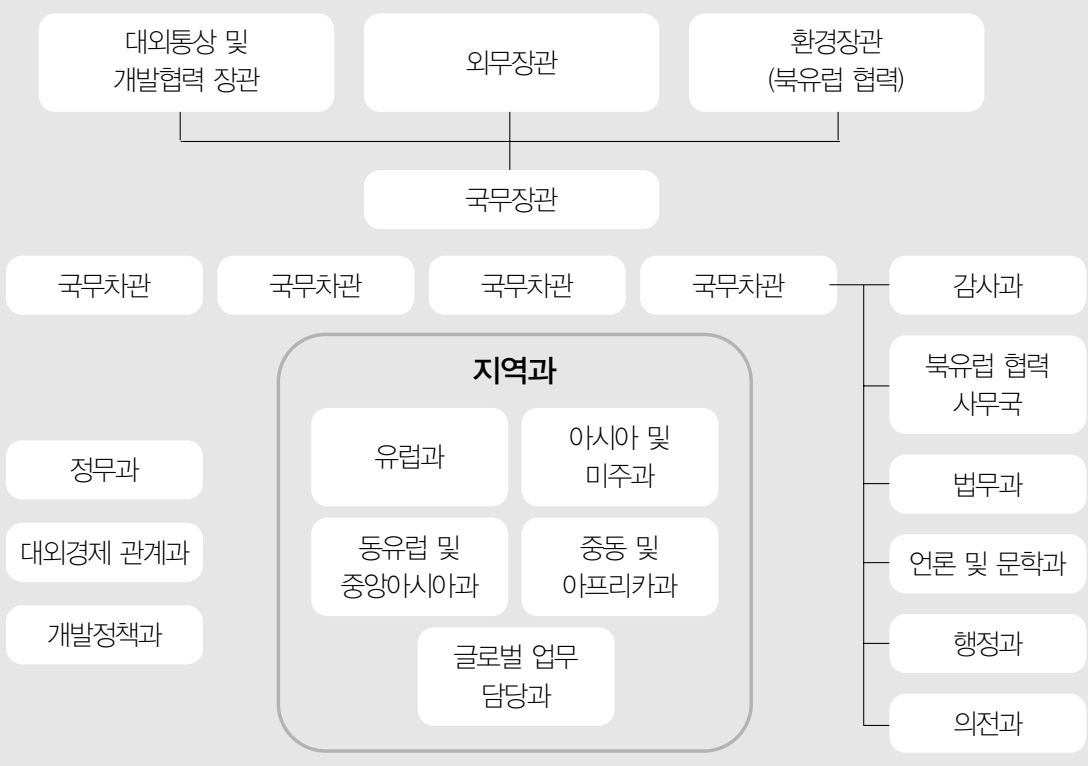

교직 직원을 모집하는 인사 시스템 그리고 (iii) 해외사무소 직원에 대한 부적절한 업무분장 및 책임성 문제임

(2)순환근무 및 해외공관 근무가 잦으며 개발협력 업 무에 전문성이 없는 직원이 관련 업무를 맡게 될 확률이 높음.

(3) 개발협력과 다른 분야의 상호작용 증진은 용이하게 조직개편되었으나 빈곤퇴치가 주류화된(Mainstreaming poverty reduction)시스템이 아님.

\section{2001년 DAC 동료평가 주요 결과}

ㅁ원조정책 및 대국민인식

- 2003년 4월 수립된 새 정부는 외교부 내 여러
부서들 간의 시너지 및 협력을 도모하기 위하여 대외통상 장관직 및 개발협력 장관직을 통합하 고 새롭게 조직을 개편함.

- 핀란드는 유엔의 천년개발목표를 지지하고 있 지만 이를 2001년 실행계획 백서에 반영하지 못 하고 있으므로 핀란드는 다음 백서에 빈곤감소 를 핀란드 개발협력의 최우선적인 목적으로 명 시하고 유엔의 천년개발목표를 반영할 필요가 있음.

ㅁ원조 규모 및 배분

-1990년대 구소련연방의 붕괴 이후 ODA 규모가 급격히 감소하였으나 새 정부는 2010년까지 유 엔목표치 ODA/GNI $0.7 \%$ 를 달성하기 위해 전 념하고 있음. 2001년 ODA/GNI 비율은 0.32\% 였으며 2007년에는 $0.45 \%$ 를 달성할 예정임. 
-원조규모가 급격히 증가할 경우를 대비해서 다 자 및 양자간 원조 내의 배분전략을 사전에 세울 필요가 있음. 특히 다자원조 및 관련 국제기구를 위한 보다 명확한 전략을 명시할 필요가 있음.

- 핀란드는 기존 여러 수원국에 분산되어 있는 원 조를 10 개의 주요 수원국으로 집중화시켜 보다 높은 원조 효과를 거두고 다른 공여국 및 수원국 에 영향을 줄 수 있는 역량을 기를 필요가 있음.

ㅁ 정책일관성

- 핀란드는 명확한 정책을 수립하고 이와 관련된 문제에 대한 분석능력을 향상시켜 개발정책의 일관성을 달성할 수 있을 것임.

- 개발도상국에 대한 공동농업정책(CAP)의 부정 적인 효과를 줄이기 위하여 이 정책을 개혁해야 하는 바, $\mathrm{EU}$ 회원국으로서 핀란드는 유럽공동 체 내 정책일관성, 특히 농산물에 대한 정책일관 성을 달성하는데 중요한 역할을 수행할 수 있을 것임.

-1998년도 백서가 제시한 대로 핀란드는 빈곤감 소에 대한 효과가 불분명한 무이자차관 사업을 단계적으로 폐지하는 것을 고려할 필요가 있음.

ㅁ 원조관리 및 실행

- 현재 핀란드 개발협력은 현지 프로젝트에 투입 될 직원 부족으로 원조의 질이 떨어지고 조정 협력 능력에 큰 차질을 경험하고 있음. 향후 크 게 증가될 $\mathrm{ODA}$ 규모 및 원조의 질과 효과성에 대한 관심을 감안하여 직원 수를 증가하고 직원 의 전문성을 개발하여 직원들의 능력배양에 신 경을 써야함.
- 개발도상국 내의 핀란드 개발협력사업에 대한 결정권이 현지 대사관에 많이 이관되었으므로 협 력 수원국 및 분야를 제한하고 권한을 위임하여 대사관 직원들의 능력을 향상시킬 필요가 있음. -현재의 개발협력 평가시스템은 개발정책과 위 원회(Executive Board of the Department for Development Policy)가 담당하고 있으므로 개 발협력 수청자와 평가자가 동일주체라는 측면 에서 신뢰하기 어려움. 뿐만 아니라 이 위원회가 다른 지역과에 대한 평가를 할 권한이 없으므로 부분적인 평가에 그침.

- 따라서 핀란드는 평가 시스템의 독립성 및 관할 범위뿐만 아니라 후속 메커니즘 및 체계적인 학 습 메커니즘을 향상시킬 여지가 많음.

- 핀란드 외교부의 체계는 빈곤감소를 명확한 우 선과제로 반영시키지 못하고 있으며 핀란드가 적극도입할 의사를 밝힌 새로운 원조모델에 관 한 지침을 만들지 못하고 있는 실정이므로 핀란 드는 국가전략을 수립하여 자국의 ODA 사업에 대해 틀(frame-work)을 마련하여 수원국과의 대화를 촉진시킬 수 있는 방법을 모색해야 함.

ㅁ 대국민 인식제고

-전반적으로 핀란드 국민들은 개발원조에 대한 지지 및 이해가 높은 편이지만 새로운 개발원조 모델 및 정책일관성에 대해 잘 알지 못하며 핀란 드 내의 문제들에 비해 개발협력에 대한 관심이 낮으므로, 핀란드 정부는 핀란드 개발협력의 새 로운 원조전략을 국민들이 이해할 수 있도록 대 국민 교육전략을 준비할 필요가 있음. 